\title{
THE BURDEN OF REGIONAL DEVELOPMENT PLANNING IN INDONESIA: A CASE STUDY OF DISCREPANCIES BETWEEN LAND USE AND SPATIAL PLANNING DOCUMENT IN BANTEN PROVINCE
}

\author{
LUTFIA HAKIM BANU MUSTAIN ${ }^{1,2}$ \& KOMARA DJAJA ${ }^{1,3}$ \\ ${ }^{1}$ Master of Planning and Public Policy, Faculty of Economics and Business, Universitas Indonesia, Indonesia \\ ${ }^{2}$ Centre for Urban and Regional Research, Universitas Indonesia, Indonesia \\ ${ }^{3}$ Urban Studies and Regional Research School of Strategic and Global Studies, Universitas Indonesia, Indonesia
}

\begin{abstract}
Regional development should be synchronized with its planning and implementation to meet the national challenge. Moreover, Indonesia frequently faces issues of land use discrepancies due to the unexpected population growth, which makes land scarcer. By grouping the issues into the socio-economic and infrastructure categories, this study tries to determine to what extent the spatial use is in accordance with the governmental spatial planning document in the case of Banten province, in the years 2011 and 2015. Using the method of Geographical Information Systems and multiple regression analysis, the study reveals which land uses tend to experience the most irregularities. The results suggest that there is a wide gap between the existing land use in Banten and the spatial planning document. The findings interestingly show that land use has changed due to agriculture, industry, housing, and trade or services as well as the population, which significantly affects the discrepancies of land use in Banten Province. It becomes the key factor that forces the stakeholders to disregard the spatial planning document. These findings can serve as the basis to advocate better policy alternatives on spatial planning, control and management to create sustainable development.
\end{abstract}

Keywords: regional development, spatial planning, discrepancies, land use.

\section{INTRODUCTION}

Banten Province is one of the new provinces in Indonesia that grows quite rapidly. The Provincial Government of Banten has divided its territory into three parts of the development work. Tangerang city, South Tangerang and Tangerang Regency belong to the Development Working Area (DWA) 1. Spatial Plan (RTRW) Banten is designed within the period of 20 years i.e. from year 2011 to 2031. The spatial plan (RTRW) of 2015 or the fourth year focuses on the search for a major gap of land use occurring in DWA 1. Based on the data of land suitability, land use discrepancies on agriculture in WKP 1 reached 6766.66 hectares or 5 percent of the total Development Working Area 1. If this problem is neglected, and thus the changing trend of land is left unexamined, the drift towards land use may continue to rise. Because of these problems, it is important to look at what factors are causing discrepancies in the Spatial planning (RTRW) land use, so that these problems can be minimized in the future.

\section{DISCREPANCIES IN LAND USE}

Being incompatible with the land use plan is a common symptom that occurs in the areas with rapid population growth. Discrepancies of land use are basically caused by land use change. The changes in land use for designation of the spatial planning document are caused by mismatches between the underlying considerations in landing plans and market players [1]. The land use change may be due to changes in land utilization in several activities such as agriculture, industry, housing, trade/services and population growth [2]. 
Changes in land values could also lead to the changes in land use [3]. Examining the factors causing mismatches of land use in southern Jakarta, the study was conducted in 65 sub-districts, resulting in an unsuitable benefit of land due to land use changes in housing, industry, trade/ services, population growth and land prices [4].

\section{METHODS AND MODEL}

This research uses quantitative method to produce a comprehensive overview of the spatial planning. Banten province is a new province in the west of Jakarta which has developed rapidly in recent years. This province has an area of 966,300 hectares with the population of $10,083,370$ inhabitants and a per capita income starting from US\$980.39 per year. GNP contributions of Banten Province on Java-Indonesia are at 6.93 percent.

Banten Province is divided into three parts of the Development Working Area (DWA). This article focuses only on DWA 1 which consists of the cities of Tangerang, South Tangerang and Tangerang Regency, which have been experiencing rapid developments in the last 5 years (Fig. 1). Spatial Plan (RTRW) is implemented in Banten province in the period of 20 years; 2011-2031. In 2015, RTRW entered its fourth year, and has seen discrepancies in sizeable land use. Based on the data of land suitability, land use discrepancies in DWA 1 on agriculture reached 6766.66 ha. Factors causing this problem should be examined; otherwise, land use discrepancy will be much harder to control in the future. Therefore, this research aims to address a question on what factors cause land use discrepancy by analyzing spatial planning documents. The findings of this research are important in that they provide information on how to minimize the possible discrepancies in land use and spatial planning. The RTRW can be better implemented with the development of a sustainable region.

The data used is the cross section consisting of thirty sub-districts in Tangerang, South Tangerang and Tangerang Regency. The data used in this research is secondary data. Data were collected primarily from the Central Bureau of Statistics (BPS), the Ministry of Agricultural and Spatial Planning, Bappeda Banten province, Dinas PBB, Department of Spatial Planning, Ministry of Public Works, and the regression method is used by using software Eviews 9.

The model used is a simple multiple regression model as used in the previous research. The dependent variable used is the total land area which is not in accordance with the document in Spatial Planning (Regional Spatial Planning). The independent variables consist of (i) changes in agricultural land; (ii) changes in industrial land; (iii) changes in housing land; (iv) changes in trading land and services; (v) the growth of the population, and; the land price [4].

In other words;

$$
\begin{gathered}
Y=\beta_{0}+\beta_{1} * \text { agricultural }+\beta_{2} * \text { Industrial }+\beta_{3} * \text { housing }+ \\
\beta_{4} \text { service }+\beta_{5} P G+\beta_{7} * \text { NTSVOTO. }
\end{gathered}
$$

Remarks:

$Y$

Housing Residential land use change (percent)

Industrial Industrial land use change (percent)

Service Land use changes trading/services (percent)

PG Population growth

NTSVOTO Non-Taxable Sales Value of Tax Object (Rupiah) 

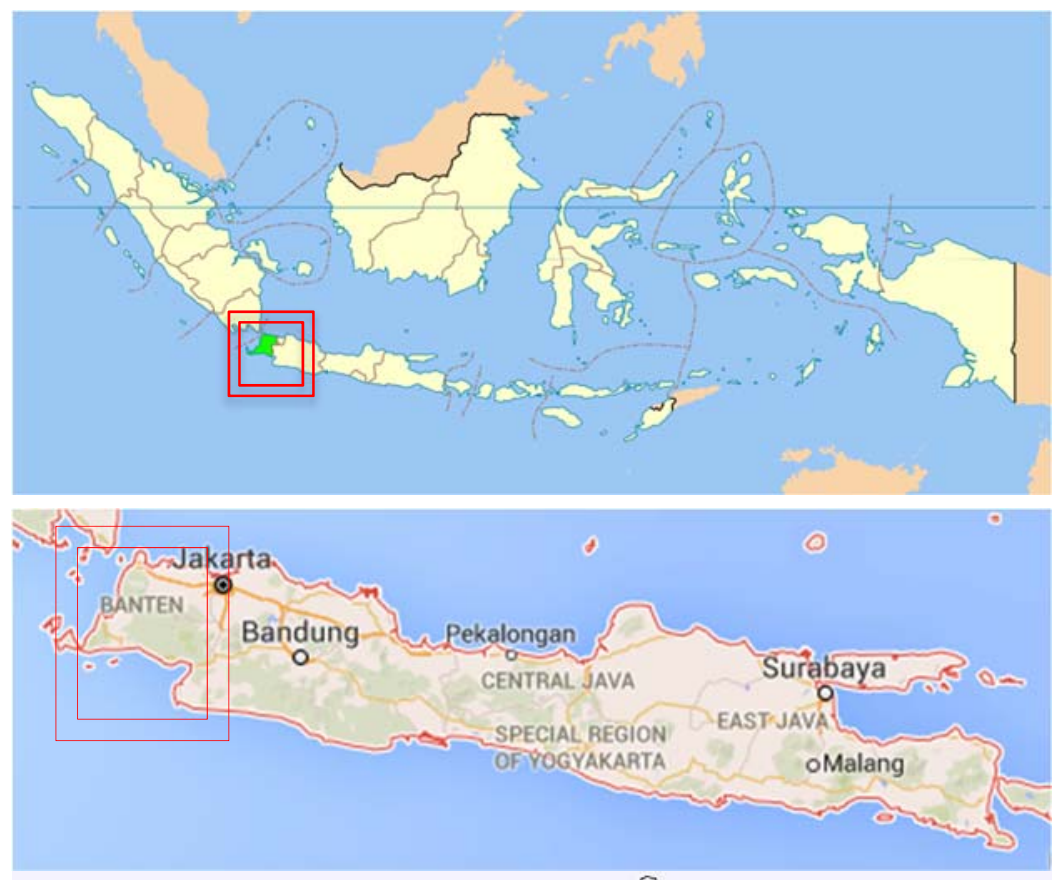

$V_{0} \quad 0$

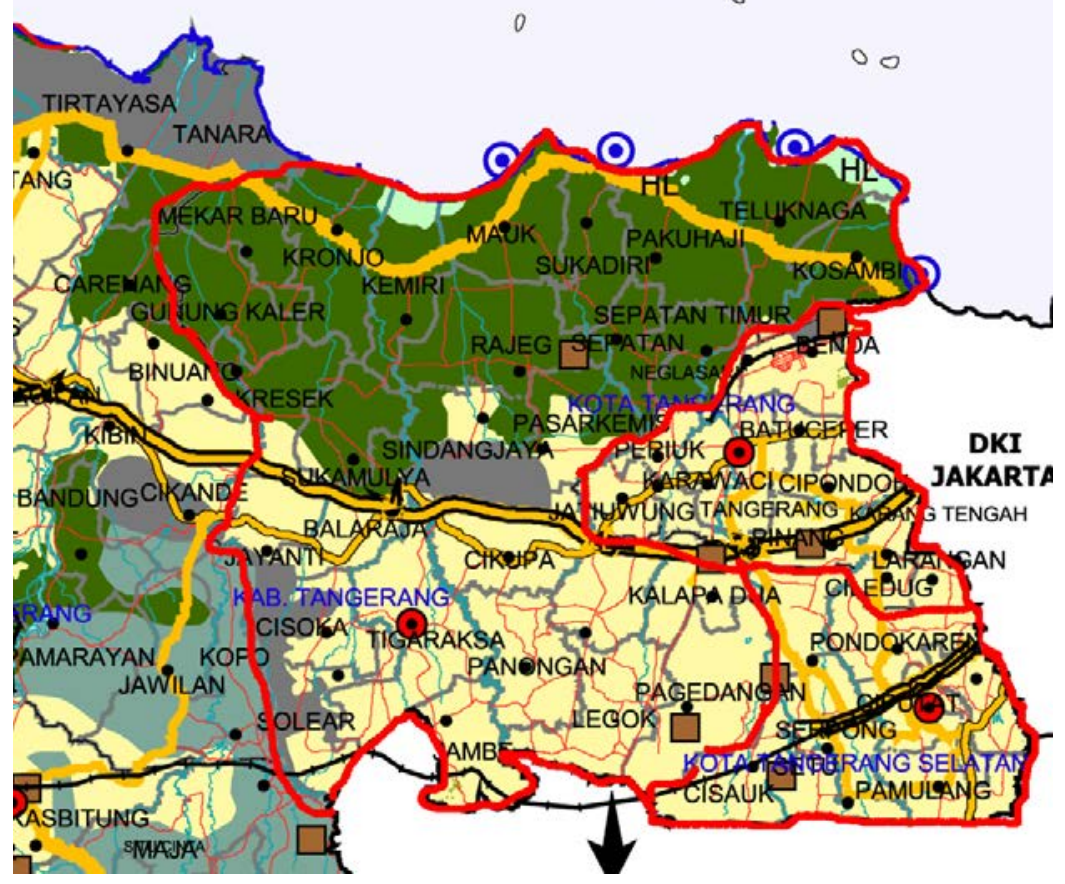

Figure 1: Map of Development Working Area 1, Banten. 
Operational definition of variables:

Agricultural Agriculture refers to the difference in the change of agricultural land use in 2011 and 2015 in 30 districts in the Development Working Area 1.

Housing Housing refers to the difference in housing land use change from 2011 to 2015. This information is obtained from the secondary data in the operation of GIS. These variables fall into the category of land use. The study conducted by Mira (2005) shows that the variable of the land use for housing changes significantly, and it influences land use discrepancies of the Spatial Planning (RTRW).

Industrial Industrial is the variable that shows the difference in residential land use change from 2011 to 2015 in 30 districts in the working area of development 1 . These variables fall into the category of land use type variables.

Service (DGJS) Service refers to land-use change and the difference in trade/services from 2011 to 2015.

PG The rate of the population growth is the variable that shows the growth of population in 2011 and 2015. The rate of the population growth is suspected as a factor in the occurrence of discrepancies of land use.

NTSVOTO The variable of taxable value represents the variable price of land in 30 districts in the working area of development 1 . It represents the variable price of land in 30 districts in the working area of development 1.

\section{RESULTS}

In responding to the question on the factors that influence land based spatial mismatches in Tangerang, South Tangerang and Tangerang Regency (DWA 1) built a model to formulate the problem. Furthermore, the model is performed through statistical tests ranging from the $t$-test on each variable, $F$-test, to adjusted $R$-squared value. Econometric testing conducted to meet the classic assumption test including normality test, multikolinear test, autocorrelation and heteroscedasticity test.

In Table 1, it appears that the variable types of land use for agriculture, industry, housing, trade/ services (DGJS), population growth was significant at $\alpha=5 \%$. The table shows that the price of land (NTSVOTO) is not a significant variable. This indicates that the price of land does not affect the discrepancies of land use on DWA 1 Banten. Based on the statistical test results above, it appears that the adjusted $R$-squared reached 0.706910 , which means that the independent variables in the model can explain the variations of discrepancies of land use amounted to $70.69 \%$. Meanwhile, $29.31 \%$ is more likely to be explained by other variables, such as per capita income, government policies, etc. Statistically, the significant ability to explain the model, seen from the figures $F$-statistic at 12.65 , can be proven by the value of $\mathrm{F}$ $(0.05 / 8.29)=2.116$ smaller than $12.65 F$-statistic. This was confirmed also by the number of significance Prob ( $F$-statistic) were very small at 0.00 .

Furthermore, the econometric testing phase in order to meet Classical assumption test includes normality test, multicollinearity test, autocorrelation and heteroscedasticity test. If the classical assumption test is met then the estimate obtained meets the assumptions BLUE (Best Linear Unbiased Estimator) in which the estimate is an unbiased, consistent and efficient. Based on the econometric results obtained on fallow Jarque normality test probability $(0.959>\alpha=5 \%)$, it does not reject Ho which means that the normality assumption is met. In heteroscedasticity test value prob. Chi-square is equal to 0.3512 because of the 
Table 1: Results of estimation model. (Source: author's data, 2016.)

\begin{tabular}{|c|c|c|c|c|}
\hline \multicolumn{4}{|c|}{$\begin{array}{l}\text { Dependent variable: BROAD } \\
\text { Method: Least squares }\end{array}$} & \\
\hline \multicolumn{4}{|c|}{ Date: $11 / 08 / 16$ Time: $15: 29$} & \\
\hline \multicolumn{5}{|c|}{$\begin{array}{l}\text { Sample: } 130 \\
\text { Included observations: } 30\end{array}$} \\
\hline Variable & Coefficient & Std. error & $t$-statistic & Prob. \\
\hline AGRICULTURE & 275.1589 & 17.94114 & 1.788410 & 0.0069 \\
\hline INDUSTRY & 372.0850 & 7.43553 & 7.844015 & 0.0000 \\
\hline HOUSING & 52.99081 & 11.71450 & 2.991380 & 0.0065 \\
\hline Services & 434.0671 & 9.6160 & 3.348869 & 0.0028 \\
\hline PG & 10.003759 & 0.003920 & 0.959033 & 0.0075 \\
\hline NTSVOTO & 0.000225 & 0.000107 & 2.093180 & 0.1476 \\
\hline $\mathrm{C}$ & 398.5338 & 158.6858 & 2.511465 & 0.0195 \\
\hline$R$-squared & 0.767549 & \multicolumn{2}{|c|}{ Mean dependent var. } & 715.1040 \\
\hline Adjusted $R$-squared & 0.706910 & \multicolumn{2}{|c|}{ SD dependent var. } & 629.6658 \\
\hline S.E. of regression & 340.8871 & \multicolumn{2}{|c|}{ Akaike info criterion } & 14.70194 \\
\hline Sum-squared resid. & 2672692. & \multicolumn{2}{|c|}{ Schwarz criterion } & 15.02889 \\
\hline Log likelihood & -213.5291 & \multicolumn{2}{|c|}{ Hannan-Quinn criter. } & 14.80654 \\
\hline$F$-statistic & 12.65762 & \multicolumn{2}{|c|}{ Durbin-Watson stat. } & 1.594391 \\
\hline $\operatorname{Prob}(F$-statistic $)$ & 0.000003 & & & \\
\hline
\end{tabular}

value prob. Chi-square $>0.05$ it can be concluded that there is no breach heteroscedasticity. In multikolinear test the correlation between the dependent variable $0.00021<\mathrm{r}<0762$ where $r<0.9$. So this model is free from multikolinear [5]. In cross section data, there is no autocorrelation problem.

So based on the test results, regression equation can be formulated as follows:

$$
\begin{aligned}
\mathrm{Y}=398.53-275.15 * \text { Agriculture }+372.08 * \text { Industry } \\
+52.99 * \text { Housing }+434.06 * \text { Service }+10 * \text { PP } \\
+0.00025 * \text { NTSVOTO }
\end{aligned}
$$

\subsection{Agriculture}

Based on the results of data processing, every $1 \%$ decrease in the extent of agricultural land use in the 4-year period (2011-2015) will increase the discrepancies of land use to Spatial Planning RTRW of 275.15 hectares. When linked to land use pattern, loss of agricultural land will contribute to deviations of land use that do not comply with the directives.

According to the spatial analysis, deviations that occur on agricultural land is heavily influenced by industrial activities amounted to $0.54 \%$ and housing amounted to $15.17 \%$ (Ministry of Public Works, 2015). Discrepancies in agricultural land use are prevalent especially in the Tangerang Regency (Fig. 2). 


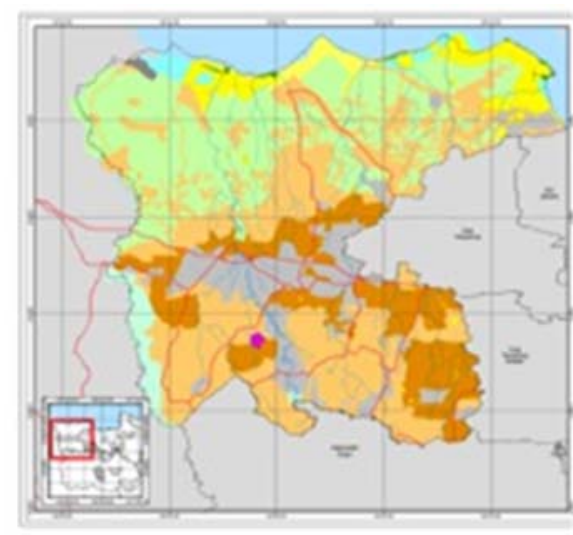

(a)

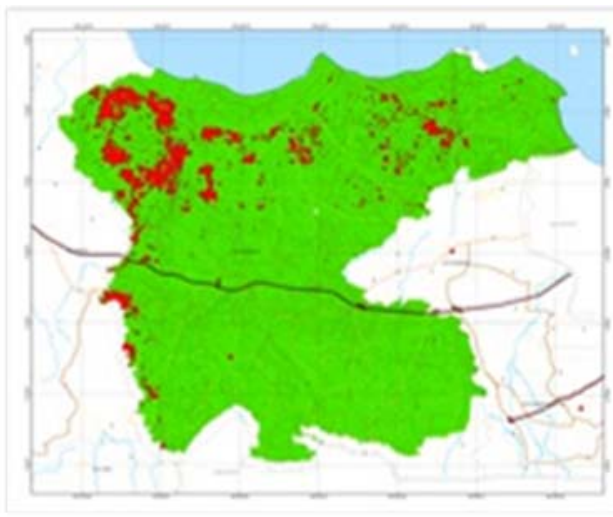

(b)

Figure 2: (a) Tangerang Regency spatial pattern; (b) Maps of discrepancies in land use at Tangerang Regency.

\subsection{Industry}

Based on the results of data processing, every $1 \%$ increase in the area of industrial land use in DWA 1 Banten Province 4-year period (2011-2015), will increase the discrepancies in land use to spatial planning (RTRW) of 372.08 hectares. Based on spatial analysis, irregularities that occur in the industrial estates can be caused by several activities such as the deployment of land-use in industrial land located in the designation of agricultural and industrial activities that cause narrowing of the broad river. Increased industrial land change in DWA 1 is quite high at 3,078.43 hectares. Discrepancies in industrial land use can be caused by the increase in industrial land that takes designated agricultural land, settlements and even river border. The number of companies of large and medium industries in the WKP is 2146 companies, and the region's most dominant industrial activities take place in South Tangerang [6].

\subsection{Housing}

Based on the results of data processing, every $1 \%$ increase in the use of land for housing in WKP 1 Banten Province 4-year period (2011-2015) will increase the non-conformity of the spatial planning of land use to 52.99 hectares. Based on the spatial analysis, deviations occur in residential land caused by the activities of trade/ services. For example, in dense residential housing zone / high density, field inspections and artifacts have been carried out to investigate land use activities of trade/ services (Complex Commercial-Lippo Karawaci Mall) in District Curug, Tangerang Regency. This activity causes mismatches in the land use designation of housing (Fig. 3).

Moreover, the increase in the residential land use in Development Working Area (DWA) 1 is caused by the population growth that also increases from 2 to 3 percent each year, so the demand for housing also increases. The increase in residential land use is also due to the growth of slums which is not in accordance with the spatial plan. 


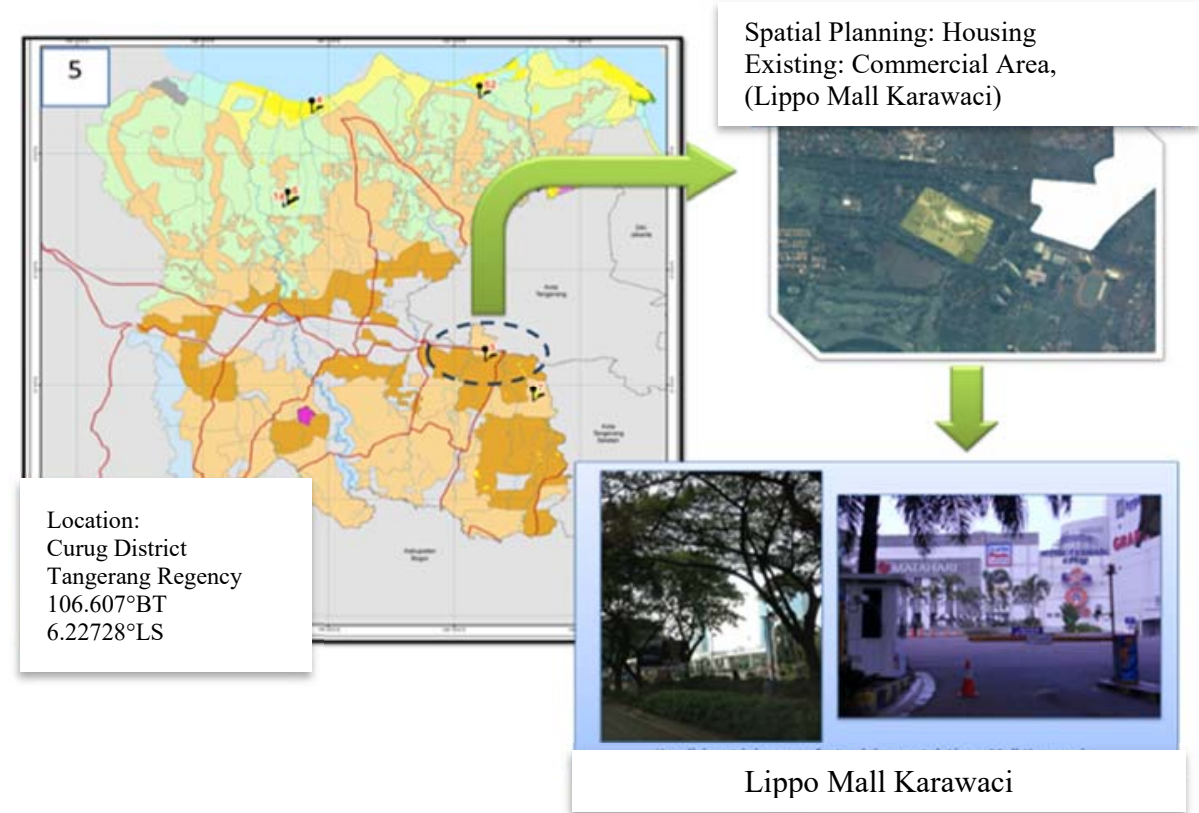

Figure 3: Commercial Complex Location Lippo Karawaci Mall Area at the residential area on Tangerang Regency [7].

\subsection{Trade and services}

Every $1 \%$ of increase in land-use trade and services in the Development Working Area (DWA) 1 Banten Province 4-year period (2011-2015) will lead to the discrepancies of land use to spatial plan (RTRW) of 434.06 hectares. Based on spatial analysis, deviation occurs on land trade/ services caused by the expansion of trade/ services on the river border line and in the area of housing allotment. Increased land use in DWA 1 is also due to the shift from the industrial sector to trade /services. A number of factories have been out of the region, especially in Tangerang city since 2013 , and the factory site has been changed to provide space for the activities of trade and services. The realization of Tangerang city's overall investment in the country has reached 148 projects worth 10.14 trillion rupiahs, whose proportion is dominated by trade/ services [8].

\subsection{Population growth}

Every $1 \%$ of the population growth in the DWA 1 Banten (Tangerang city, South Tangerang and Tangerang Regency) in the period of 2011-2015 will increase the non-conformity of the spatial planning of 10 hectares of land use. A considerable contribution to the discrepancies of land use is due to the increasing number of inhabitants in the DWA 1 in the past four years by 1 to 2 percent annually. This population growth will lead to the increasing demand for housing. The high rate of population growth can be caused by the development of services and industrial activities, which will have an impact on increasing the space requirement [9]. 


\subsection{Land prices}

The sale value of tax object or the variable price of land in this study does not have significant effects on the occurrence of nonconformities of land. This can be caused by several things. First, the price of land in different regions is uneven. There is no difference in price between strategic and isolated land. Some districts, especially those in rural areas, have very low land prices, and the increase in the past four years has been insignificant. Some of them are located in Tangerang Regency. Second, the tax reduction policy for agricultural land is intended to minimize the conversion of agricultural land to make some land less valuable. This suggests that the development of industrial activity, property (housing) and trade in services are more important factors of inconsistency than land prices as a land use change variable.

Table 2 shows discrepancies with the land utilization plan reaching 6,766.66 hectares. There are 404.54 hectares of land utilization mismatches occurring in the city of Tangerang, 788.96 hectares of land use discrepancies in South Tangerang and 5,573.16 hectares of land use discrepancies in the district of Tangerang. The third area is a buffer area of the capital of Jakarta. In other words, it belongs to the territory of suburban Jakarta. Thus, the rising demand for urban land tends to be met primarily by converting land at the periphery of the existing built-up area [11]. The most dominant region with designated agricultural land conversion experience is these three areas. Suburbs should be of particular concern, because of the development in the future. The region has agricultural potential which needs to be maintained to ensure food security in urban areas.

DWA 1 Banten Province is a part of extended metropolitan region (EMR). Its emergence along with the growth of the region has generated environmental sustainability problems that continue to increase in scale and impacts [12].

By looking at the trend of land use change and its contribution to the discrepancies of land use can be decisive information for spatial policy. The information is needed to determine the measures or policy control of spatial planning in order to create sustainable development.

\section{CONCLUSION}

This paper shows several findings. Factors that significantly affect the mismatch of land use in the area of development work 1 Banten (Tangerang City, South Tangerang and Tangerang Regency) based on data from 30 districts in the period 2011 to 2015 are, among others, the change of use of agricultural land, industrial, residential, trade/ services (DGJS) and population growth (PG). Agriculture has a negative and significant relationship, while the other variables show a positive and significant relationship. Factors such as land prices

Table 2: Extensive and comprehensive regional land discrepancies in Development Working Area 1 [10].

\begin{tabular}{llll}
\hline & Kota/Kabupaten & Total discrepancies & Total area \\
\hline 1 & Tangerang City & 404.54 & $17,819.72$ \\
2 & South Tangerang & 788.96 & $18,941.63$ \\
3 & Tangerang Regency & 5573.16 & $98,770.36$ \\
& Total & 6766.66 & $135,531.71$ \\
& Percentage & $5 \%$ & $100 \%$ \\
\hline
\end{tabular}


(Non-Taxable Sales Value of Tax Object) in this study do not show significant results, which means there is not any influence of land prices to the level of mismatched of land use in the city of Tangerang, South Tangerang and Tangerang Regency. The changes in agricultural, industrial, residential and trade/ services land have caused mismatches of land use along with increased investment in industry, services and housing. Seeing the changes in land use for trade/ services as the most significant factor of discrepancies of land use, the government can reinforce its control on the improvement of spatial land use change for trade/ services in the areas of development work 1 .

The government can also prioritize spatial control activities to accord with the level of contribution of land use change on land use existing mismatches from the start, with the highest as the lowest. Knowing that the trend of land use change leads to discrepancies of land use can facilitate the government in determining the spatial direction control policies better to achieve sustainable development.

\section{ACKNOWLEDGEMENT}

This work is supported by the Internationally Indexed Publicity Grant for Final Assignment of Post-Graduate Student, Universitas Indonesia, Grant funded by Universitas Indonesia, contract no. 2154/UN2.R12/HKP.05.00/2016.

\section{REFERENCES}

[1] Zulkaidi, D., Pemahaman Perubahan Pemanfaatan Lahan Kota Sebagai Dasar Bagi Kebijakan Penaganganannya, Penerbit ITB: Bandung, 1999.

[2] Hoshino, S., Regression Analysis on Factors of Land Use Change in Japan, 1996.

[3] Reksohadiprojo, S. \& Karseno, A.R., Ekonomi Perkotaan, FE UGM: Yogyakarta, 1981.

[4] Indrayani, M., Analisis Perubahan Penggunaan Lahan dan Faktor-Faktor Ketidkasesuaian Penggunaan Lahan, FE UI: Salemba, 2005.

[5] Gujarati, D., Dasar-Dasar Ekonometrika, Erlangga: Jakarta, 2008.

[6] Badan Pusat Statistik Kota Tangerang Selatan, Jumlah Perusahaan Tangerang Selatan, 2014.

[7] Ministry of Spatial and Planning, Example of Land Use Discrepancies, 2016.

[8] Board of Investment and Integrated Licensing BPMPTSP, Investasi Kota Tangerang, 2014.

[9] Tjiptoherijanto, Mobilitas Penduduk an Pembangunan Ekonomi, Naskah, No. 20, 2000.

[10] Bappeda Banten, Extensive and Comprehensive Regional Land Discrepancies Tangerang City South Tangerang and Tangerang Regency, 2015.

[11] Dunkerley, H.B., Urban Land Policy Issues and Opportunities, IBRD/World Bank: Washington, DC, 1983.

[12] Firman, T., New town development in Jakarta metropolitan region: A perspective of spatial segregation. Habitat International, 28, pp. 349-368, 2004. 